\title{
The human equilibrative nucleoside transporter I mediates in vitro cytarabine sensitivity in childhood acute myeloid leukaemia
}

\section{Hubeek ${ }^{*, 1,8}$, RW Stam ${ }^{4,8}$, GJ Peters' ${ }^{2}$ R Broekhuizen', JPP Meijerink ${ }^{4}$, ER van Wering ${ }^{5}$, BES Gibson ${ }^{6}$, U Creutzig', CM Zwaan', J Cloos', DJ Kuik ${ }^{3}$, R Pieters ${ }^{4}$ and GJL Kaspers'}

'Department of Pediatric Hematology/Oncology, VU University Medical Center, De Boelelaan 1/17, Postbus 7057, 1007 MB, Amsterdam, The Netherlands; ${ }^{2}$ Department of Medical Oncology, VU University Medical Center, De Boelelaan I I 17, Postbus 7057, 1007 MB, Amsterdam, The Netherlands; ${ }^{3}$ Department of Clinical Epidemiology and Biostatistics, VU University Medical Center, De Boelelaan II I 7, Postbus 7057, I 007 MB,

Amsterdam, The Netherlands; ${ }^{4}$ Department of Pediatric Oncology/Hematology, Erasmus MC/Sophia Children's Hospital, Rotterdam, The Netherlands; ${ }^{5}$ The Dutch Childhood Oncology Group (DCOG), The Hague, The Netherlands; ${ }^{6}$ MRC Childhood Leukaemia Working Party, UK; ${ }^{7}$ AML BFM-Study Group, Münster, Germany

Cytarabine (ara-C) is the most effective agent for the treatment of acute myeloid leukaemia (AML). Aberrant expression of enzymes involved in the transport/metabolism of ara-C could explain drug resistance. We determined mRNA expression of these factors using quantitative-real-time-PCR in leukemic blasts from children diagnosed with de novo AML. Expression of the inactivating enzyme pyrimidine nucleotidase-I (PN-I) was I.8-fold lower in FAB-M5 as compared to FAB-MI/2 $(P=0.007)$. In vitro sensitivity to deoxynucleoside analogues was determined using the MTT-assay. Human equilibrative nucleoside transporter-I (hENTI) mRNA expression and ara- $C$ sensitivity were significantly correlated $\left(r_{p}=-0.46 ; P=0.001\right)$, with three-fold lower $h E N T I m R N A$ levels in resistant patients $(P=0.003)$. hENTI mRNA expression also seemed to correlate inversely with the $\mathrm{LC}_{50}$ values of cladribine $\left(r_{p}=-0.30 ; P=0.04\right)$, decitabine $\left(r_{P}=-0.29 ; P=0.04\right)$ and gemcitabine $\left(r_{P}=-0.33 ; P=0.02\right)$. Deoxycytidine kinase $(d C K)$ and cytidine deaminase $(C D A)$ mRNA expression seemed to correlate with in vitro sensitivity to gemcitabine $\left(r_{\mathrm{p}}=-0.3 \mathrm{l} ; P=0.03\right)$ and decitabine $\left(r_{P}=0.33 ; P=0.03\right)$, respectively. The $d C K / P N-I$ ratio correlated inversely with $L C_{50}$ values for gemcitabine $\left(r_{P}=-0.45\right.$, $P=0.00 \mathrm{I})$ and the $d C K / C D A$ ratio seemed to correlate with $L C_{50}$ values for decitabine $\left(r_{p}=-0.29 ; 0.04\right)$. In conclusion, decreased expression of $h E N T I$, which transports ara-C across the cell membrane, appears to be a major factor in ara- $C$ resistance in childhood AML.

British Journal of Cancer (2005) 93, I388- |394. doi:I0.1038/sj.bjc.660288 I www.bjcancer.com (c) 2005 Cancer Research UK

Keywords: childhood acute myeloid leukaemia; deoxynucleoside analogues; cytarabine; hENTI

\begin{abstract}
Although the treatment of acute leukaemia has improved significantly over the past few decades, the prognosis of acute myeloid leukaemia (AML) remains relatively poor. For newly diagnosed patients, the compete remission (CR) rate reaches $85-$ $90 \%$ with standard induction chemotherapy (Creutzig et al, 1999; Hann et al, 2004). However, about $30-50 \%$ of the patients that achieve CR relapse from minimal residual disease cells that apparently survived chemotherapy (Hann et al, 2004), giving rise to a more resistant leukaemia. Resistance to chemotherapy therefore remains a major obstacle in the treatment of AML.

In combination with anthracyclines, $1-\beta$-D-arabinofuranosylcytosine (cytosine arabinoside, cytarabine, ara-C) is the most effective agent for the treatment of AML. Ara-C is a deoxynucleoside analogue that has to be converted into its active triphosphate derivative (ara-CTP) to exert its cytotoxic effect (Grant, 1998). AraCTP is then incorporated into the DNA causing chain termination, resulting in a block in DNA synthesis and facilitating programmed
\end{abstract}

*Correspondence: Dr I Hubeek; E-mail: isabelle.hubeek@vumc.nl

${ }^{8}$ These authors contributed equally to the work.

Received 25 May 2005; revised 20 September 2005; accepted 27 October 2005 cell death (Figure 1). Ara-C is a hydrophilic molecule and as such requires facilitated diffusion via nucleoside-specific membrane transport carriers to enter cells (Cass et al, 1998; Clarke et al, 2002). The human equilibrative nucleoside transporter (hENT1) is responsible for $80 \%$ of ara-C influx in human leukemic blast cells (Sundaram et al, 2001; Clarke et al, 2002). Inside the cell, conversion of ara-C into ara-CMP by deoxycytidine kinase (dCK) is believed to be the rate-limiting step in the metabolism of ara-C (Liliemark et al, 1985; Plunkett et al, 1987). Subsequently, ara-CMP is phosphorylated into ara-CDP by nucleoside monophosphate kinases, which in turn finally is phosphorylated into ara-CTP by diphosphate kinases (Hande and Chabner, 1978). Inactivation of ara-C results from deamination by cytidine deaminase (CDA) (Laliberte and Momparler, 1994). In addition, ara-CMP can be dephosphorylated by pyrimidine nucleotidase I (PN-I) (Amici et al, 1997) as well as deaminated by deoxycytidylate deaminase (dCMPD) (Mancini and Cheng, 1983). Inactivation by these enzymes decreases the amount of ara-CTP and thereby limits ara-C mediated cytotoxicity. Deoxycytidine triphosphate (dCTP) is thought to inhibit the phosphorylation of ara-C (by feedback inhibition of dCK) and the incorporation of ara-CTP into DNA (by competition for DNA polymerase). Increased intracellular dCTP 


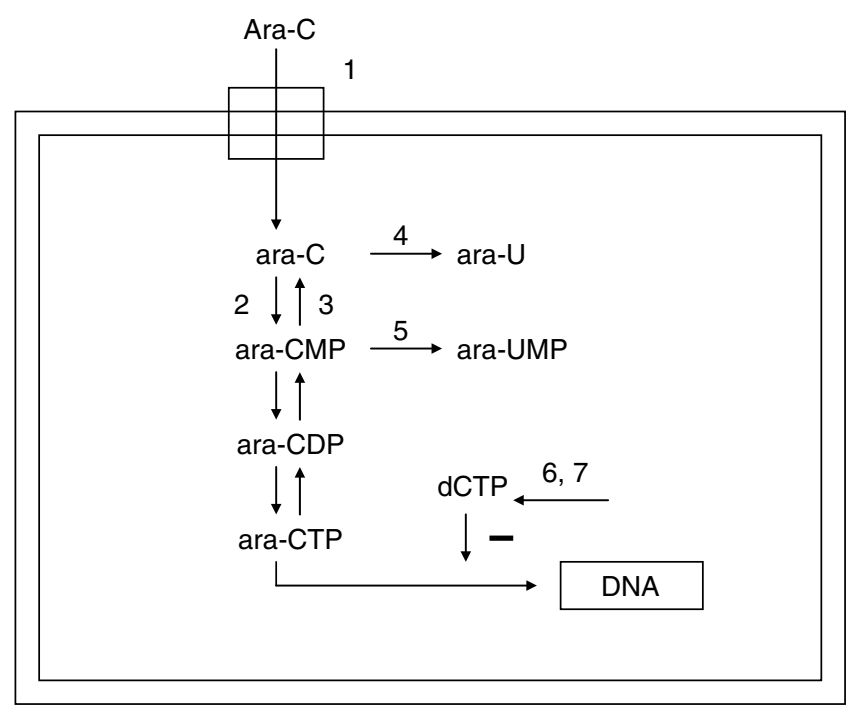

Figure I Metabolism of ara-C. Ara-C enters the cell via the equilibrative nucleoside transporter I (hENTI; I). Inside the cell, ara-C is phosphorylated to ara-CMP by deoxycytidine kinase (dCK; 2). Ara-CMP is subsequently phosphorylated to ara-CTP, the active metabolite. Incorporation of ara-CTP into the DNA blocks DNA synthesis and leads to cell death. Ara-CTP formation can be obstructed. Pyrimidine nucleotidase I (PN-I; 3) opposes the action of dCK. Cytidine deaminase (CDA; 4) and deoxycytidylate deaminase (dCMPD; 5) convert ara-C to ara- $U$, and araCMP to ara-UMP, respectively. Increased intracellular dCTP pools antagonise the formation of ara-CTP. dCTP can be synthesised directly via the de novo pathway by ribonucleotide reductase (6). CTP synthetase (CTPs; 7) converts uridine triphosphate to CTP. Because aberrant expression of these enzymes may be related to in vitro sensitivity to ara$\mathrm{C}$, and other deoxynucleoside analogues, we determined the mRNA expression of the target genes in AML.

pools therefore antagonise the formation of ara-CTP (Liliemark and Plunkett, 1986; White and Capizzi, 1991). dCTP can be synthezised directly via the de novo pathway by ribonucleotide reductase (RR) (Smith and Karp, 2003). Ribonucleotide reductase catalyses the conversion of ribonucleotides into deoxyribonucleotides (Smith and Karp, 2003). Mammalian RR is made up of two subunits (Reichard and Ehrenberg, 1983). The M1 subunit is the binding site for nucleotides and the second subunit, M2, is a metal binding site that requires both a non-haeme iron and a tyrosinefree radical for its activity (Smith and Karp, 2003). CTP synthetase (CTPs) is responsible for the conversion of uridine triphosphate (UTP) into CTP and has a high activity in several malignancies, including acute lymphoblastic leukaemia (Verschuur et al, 1998).

In addition to ara-C a variety of other deoxynucleoside derivatives are active in both haematological and solid malignancies. The purine analogues 2-chlorodeoxyadenosine (cladribine; $2-\mathrm{CdA}$ ) and fludarabine (F-ara-A) are active against indolent lymphoid malignancies and are currently also used for the treatment of hairy-cell leukaemias and chronic and acute leukaemias, respectively (Frewin and Johnson, 2001). The pyrimidine analogue gemcitabine $(\mathrm{dFdC})$ has activity in various solid malignancies and some haematological disorders (Van Moorsel et al, 1997). The cytidine analogue 5-aza-2'-deoxycytidine (decitabine; DAC) is a potent hypomethylating agent and has shown to be active in the treatment of haematological malignancies such as AML, chronic myeloid leukaemia (CML) and myelodysplastic syndrome (Lyons et al, 2003). These compounds are activated intracellularly via the same metabolic pathway as ara-C. Impaired transport decreased activation of deoxynucleoside analogues to their cytotoxic tri-phosphate form or increased dCTP levels may result in resistance to this clinically important group of compounds. The objective of our study was to identify possible mechanisms of resistance to deoxnucleoside analogues, particularly ara-C, in the leukemic blasts of paediatric AML patients. We therefore determined the mRNA level of the following targets: $h E N T 1, d C K, P N-I, C D A, d C M P D, C T P$ synthetase and $R R$ (subunit 1 and 2) in leukaemic blasts from children with newly diagnosed AML. In addition, we studied the mRNA expression levels of the target enzymes in different AML FAB-type subgroups. Finally, the expression levels of the above-mentioned enzymes were correlated to in vitro sensitivity to deoxynucleoside analogues (ara-C, 2-CdA, DAC, F-ara-A and dFdC).

\section{MATERIALS AND METHODS}

\section{Patient samples}

Bone marrow and/or peripheral blood samples were collected from untreated children diagnosed with de novo AML. The following groups participated in this study and provided patient samples: (1) The Dutch Childhood Oncology Group (DCOG), The Hague, The Netherlands; (2) MRC Childhood Leukaemia Working Party, UK and (3) The AML BFM-study Group, Münster, Germany. Central review of the diagnosis, data collection as well as review of FABclassification were carried out by reference laboratories and data centres of these groups. The FAB-classification was performed according to the criteria by Bennett et al (1985), including the modifications to diagnose FAB M0 and FAB M7. Samples were collected at the VU university medical centre between October 1990 and September 2002.

\section{Treatment protocols}

Patients were treated on intensive ara-C/anthracyclines based protocols in the Netherlands, Germany and the UK (protocols DCOG AML 87 and 97, BFM 93 and 98 and MRC AML 12). The treatment protocols have been reported in detail elsewhere (Creutzig et al, 1995, 1999; Hann et al, 2004; Slats et al, 2005).

In the AML BFM 93 study, the patients were stratified according to risk group. At diagnosis, patients were randomised between daunorubicin (plus ara-C and etoposide, ADE) and idarubicin (plus ara-C and etoposide, AIE) induction therapy. For HR patients, one of the intensification blocks was changed to highdose ara-C with mitoxantrone (HAM). Sibling SCT was advised for HR patients in first CR. SR patients did not recieve HAM. Protocol AML BFM 98 consisted of induction with the idarubicin block, followed by HAM. In the consolidation phase, patients were randomised for either recieving the 6-week consolidation block followed by one intensification block $v s$ three intensive courses of chemotherapy.

The DCOG AML 87 protocol was based on the concurrent AMLBFM protocol. In brief, DCOG AML 87 started with an 8-day induction course followed by a 6-week consolidation block. Then two intensification courses were given. Intrathecal chemotherapy was given as central nervous system prophylaxis. Contrary to the AML BFM 87 study, no maintenance therapy was given. Sibling donor allogeneic STC was advised for HR patients in first CR.

Patients enrolled in the DCOG AML 97, which was identical to the MRC AML12 protocol, were stratified according to cytogenetics. Good risk patients (defined as patients with $t(8 ; 21)$, inv(16) or $t(15 ; 17)$ ) were not eligible for SCT. Patients were randomised to induction treatment with either ADE (ara-C, daunorubicin and etoposide) or MAE (mitoxantrone, ara-C and etoposide), followed by a four or five (randomised) treatment courses. The fifth course was high-dose ara- $\mathrm{C}$ and asparaginase. If a matched sibling donor was available, then SCT was recommended as the fourth or fifth course (randomised). 


\section{Cells}

Mononuclear cells were isolated by density gradient centrifugation using Lymphoprep (density $1.077 \mathrm{~g} \mathrm{ml}^{-1}$; Nycomed Pharma, Oslo, Norway), and centrifuged at $480 \mathrm{~g}$ for $15 \mathrm{~min}$ at room temperature. Cells were washed and resuspended in culture medium consisting of RPMI 1640 medium (Dutch modification without L-glutamine; Gibco BRL, Life Technologies, Breda, The Netherlands), 20\% fetal calf serum (FCS; Integro, Zaandam, The Netherlands), $2 \mathrm{~mm}$ L-glutamine (Gibco BRL, Life Technologies), $5 \mu \mathrm{g} \mathrm{ml}^{-1}$ transferrin, $5 \mathrm{ng} \mathrm{ml}^{-1}$ sodium selenite (ITS media supplement; Sigma, St Louis, MO, USA), $100 \mathrm{IU} \mathrm{ml}^{-1}$ penicillin, $100 \mu \mathrm{g} \mathrm{ml}^{-1}$ streptomycin, $0.125 \mu \mathrm{g} \mathrm{ml}^{-1}$ fungizone (Gibco BRL, Life technologies), and $0.2 \mathrm{mg} \mathrm{ml}^{-1}$ gentamycin (Gibco BRL, Life technologies). Contaminating normal cells were removed by immunomagnetic beads (in case of lymphocytes) or by freezing in liquid nitrogen and thawing (in case of granulocytes) (Kaspers et al, 1994b). All samples contained at least $80 \%$ leukemic cells, as determined morphologically on May-Grunwald-Giemsa (Merck, Darmstadt, Germany) stained cytospins. A minimum of $5 \times 10^{6}$ cells were lysed in RNAzol or Trizol reagent (Gibco BRL, Life technologies) and stored at $-80^{\circ} \mathrm{C}$ until RNA extraction. The majority of samples were received and processed within $24 \mathrm{~h}(n=42)$, eight samples however were received and processed within $48 \mathrm{~h}$.

\section{RNA extraction and cDNA synthesis}

Total cellular RNA was isolated from $5 \times 10^{6}$ cells using RNAzol or Trizol reagent, according to the manufacturer's protocol. After precipitation with ethanol, RNA pellets were dissolved in water. The RNA was quantitated spectrophotometrically. cDNA synthesis was performed as described by Stam et al (2003). Briefly, following a denaturation step of $5 \mathrm{~min}$ at $70^{\circ} \mathrm{C}, 1 \mu \mathrm{g}$ of RNA was reverse transcribed to single-stranded cDNA using a mix of random hexamers $(2.5 \mu \mathrm{M})$ and oligo dT primers $(20 \mathrm{nM})$. The RT reaction was performed in a total volume of $25 \mu$ l containing $0.2 \mathrm{~mm}$ of each dNTP (Amersham Pharmacia, Biotech, Piscataway, NJ, USA) $200 \mathrm{U}$ Moloney murine leukaemia virus reverse transcriptase (M-ML RT; Promega, Madison, WI, USA), and $25 \mathrm{U}$ RNAsin (Promega) at $37^{\circ} \mathrm{C}$ for $30 \mathrm{~min}, 42^{\circ} \mathrm{C}$ for $15 \mathrm{~min}$ and $94^{\circ} \mathrm{C}$ for $5 \mathrm{~min}$. The obtained cDNA was diluted to a final concentration of $8 \mathrm{ng} \mu \mathrm{l}^{-1}$. Samples were stored at $-80^{\circ} \mathrm{C}$.

\section{Quantitative real-time PCR (Taqman technology)}

The mRNA expression levels of $d C K, P N-I, C D A, d C M P D, h E N T 1$, $R R 1$ and $R R 2$, CTP synthetase and the endogenous housekeeping gene encoding glyceraldehyde-3-phosphate dehydrogenase $(G A P D H)$ as a reference were quantified using real-time PCR analysis (Taqman) on an ABI Prism 7700 sequence detection system (PE Applied Biosystems). Amplification of specific PCR products was detected using dual-fluorescent nonextendable probes labelled with 6-carboxyfluorescein (FAM) at the $5^{\prime}$ end and with 6-carboxytetramethylrhodamine (TAMRA) at the $3^{\prime}$ end. All primers and probe combinations were designed using the OLIGO 6.22 software (Molecular Biology Insights, Cascade, CO, USA) and purchased from Eurogentec (Seraing, Belgium). Primers and probes used to detect hENT1, dCK, PN-I, CDA and $d C M P D$ have been reported before (Stam et al, 2003). For CTPs and RR1 and $R R 2$ primers and probes are listed in Table 1.

As described before (Stam et al, 2003), real-time PCR was performed in a total reaction volume of $50 \mu$ l containing TaqMan buffer A (Applied Biosystems, Nieuwerkerk a/d Ijssel, The Netherlands), $4 \mathrm{~mm} \mathrm{MgCl}_{2}, 200 \mu \mathrm{M}$ of each dNTP (Amersham Pharmacia Biotech), $300 \mathrm{~nm}$ forward and reverse primer, $50 \mathrm{~nm}$ dual-labelled fluorogenic internal probe, 1.25 U AmpliTaq Gold DNA polymerase (Applied Biosystems) and $40 \mathrm{ng}$ of cDNA as a template. Samples were heated for $10 \mathrm{~min}$ at $95^{\circ} \mathrm{C}$ to activate the
Table I Primers and probe combinations used for the quantitative realtime PCR

\begin{tabular}{ll}
\hline Gene & Sequence \\
\hline RRI & \\
Forward & 5'-GTG TGG GAA ATC TCT CAG A-3' \\
Reverse & 5'-CCA TGG CTG CTG TGT T-3' \\
Probe & 5'-(FAM)-CAA ACT CAC TAG TAT GCA CTT CTA \\
& CGG-(TAMRA)-3' \\
RR2 & \\
Forward & 5'-AGG GGC TCA GCT TGG-3' \\
Reverse & 5'-GGG GCA GCT GCT TTA G-3' \\
Probe & 5'-(FAM)-CGT CCT GGC CAG CAA GAC-(TAMRA)-3' \\
CTPS & \\
$\quad$ Forward & 5'-ATC CCG TGG TCG TAG AC-3' \\
Reverse & 5'-TGG CCA ACA AAC TTC AA-3' \\
Probe & 5'-(FAM)-AAC ACA ACC CAG GGC AGA TG-(TAMRA)-3' \\
\hline
\end{tabular}

$R R I=$ ribonucleotide reductase subunit I; RR2 = ribonucleotide reductase subunit 2; CTPs $=$ CTP synthetase.

AmpliTaq Gold DNA polymerase and amplified during 40 cycles of $15 \mathrm{~s}$ at $95^{\circ} \mathrm{C}$ and $60 \mathrm{~s}$ at $60^{\circ} \mathrm{C}$. The relative mRNA expression levels of the target genes in each patient were calculated using the comparative cycle time $\left(C_{\mathrm{t}}\right)$ method (Meijerink et al, 2001). Briefly, this PCR $C_{\mathrm{t}}$ value is the cycle number at which emitted fluorescence exceeds $10 \times$ the standard deviation (s.d.) of baseline emissions as measured from cycles $3-15$. The $C_{\mathrm{t}}$ of the target gene is normalised to the GAPDH PCR $C_{\mathrm{t}}$ value by subtracting the GAPDH $C_{\mathrm{t}}$ value from the target $C_{\mathrm{t}}$ value. The mRNA expression level for each target PCR relative to GAPDH can was calculated using the following equation:

$$
\text { relative mRNA expression }=2^{-\left(C_{t} \text { target }-C_{t} \text { GAPDH }\right)} \times 100 \%
$$

\section{In vitro cytotoxicity assay}

In vitro cytotoxicity of the deoxynucleoside analogues ara-C (Cytosar; Pharmacia \&Upjohn, Woerden, The Netherlands), 2-CdA (Leustatin, Ortho Biotech, USA), DAC (Decitabine, kindly provided by PCH Pharmachemie bv, Haarlem, The Netherlands), F-ara-A (Fludara, Schering AG, The Netherlands), Gemcitabine (Gemzar, Eli Lilly, Houten, The Netherlands) was determined using the MTT-assay as described previously (Pieters et al, 1990). Briefly, cells were cultured in round-bottomed 96-well microtitre plates in the presence of six concentrations of different drugs, in the following ranges: ara-C $(0.04-41.0 \mu \mathrm{M}) ; 2-\mathrm{CdA}(0.001-$ $140.0 \mu \mathrm{M}) ; \operatorname{DAC}(11.0 \mu \mathrm{M}-11.0 \mathrm{mM}) ;$ F-ara-A $(0.04-44.0 \mu \mathrm{M})$ and $\mathrm{dFdC}(0.04-13.0 \mathrm{~mm})$. Cells without drugs were included as controls and cells in culture medium only were used as blanks. The plates were cultured for 4 days at $37^{\circ} \mathrm{C}$ in humidified air containing $5 \% \mathrm{CO}_{2}$, after which $10 \mu \mathrm{l}$ of 3-[4,5-dimethylthiazol-2yl]-2,5 diphenyl tetrazoliumbromide (MTT; $5 \mathrm{mg} \mathrm{m}^{-1}$, Sigma Aldrich, Zwijndrecht, The Netherlands) was added and the plates were incubated for an additional $6 \mathrm{~h}$. Only viable cells are able to reduce MTT tetrazolium salt to purple/blue formazan crystals. The formazan crystals were dissolved using acidified isopropanol (0.04 N HCl-isopropyl alcohol) and the optical density (OD), which is linearly related to the number of viable cells, (Klumper et al, 1995) was measured spectophotometrically at 562 and $720 \mathrm{~nm}$. After subtraction of the blank values, the leukemic cell survival (LCS) was calculated by the following equation: $\mathrm{LCS}=\left(\mathrm{OD}_{\text {day } 4}\right.$ treated well/mean $\mathrm{OD}_{\text {day } 4}$ control wells $) \times 100 \%$. Drug sensitivity was expressed as the $\mathrm{LC}_{50}$ value, the drug concentration lethal to $50 \%$ of the leukemic cells. Evaluable results were obtained when a 
minimum of $70 \%$ leukemic cells was present at day 4 and when the control OD was more than or equal to 0.050 (Kaspers et al, 1994a). Sample source (bone marrow or peripheral blood) and cryopreservation do not influence the results obtained by cellular drug resistance testing and were therefore analysed together (Kaspers et al, 1991).

\section{Statistics}

Distribution of measurement values was characterised with median and quartiles (25th-75th percentiles). Due to the strongly skewed character of the distributions, analyses were performed on the log-transformed measurements. For significance, a two-tailed level of $\alpha=0.01$ was used. $P$-values between 0.01 and 0.05 were considered to indicate a trend for significance. Pearson correlations were used to describe relations between variables. AML patient samples were divided in thre subgroups, according to their sensitivity to ara-C: sensitive $\left(\mathrm{LC}_{50}<0.98 \mu \mathrm{M}\right)$, intermediate $\left(0.98<\mathrm{LC}_{50}<5.18 \mu \mathrm{M}\right)$ and resistant $\left(\mathrm{LC}_{50}>5.18 \mu \mathrm{M}\right)$ (cutoffs based on Zwaan ChM, Blood, 2000) (Zwaan et al, 2000) and a one-way ANOVA was carried out on hENT1 for these three sensitivity groups. Stepwise modelling on the log-transformed $\mathrm{LC}_{50}$ values was used to unravel the relative importance of the possible indicators.

\section{RESULTS}

\section{Patient characteristics}

Fifty-five AML patient samples with $\mathrm{LC}_{50}$ values for ara-C, cladribine, decitabine, fludarabine and gemcitabine (determined with the MTT assay) were selected for RNA isolation. We were unable to isolate a sufficient amount of RNA from five of these samples. Thus, the study population consists of 50 newly diagnosed paediatric AML patients. Patient characteristics are listed in Table 2. This selected group of AML patients did not differ significantly with regard to age $(P=0.30)$, WBC $(P=0.14)$, sex $(P=0.39)$ or in vitro sensitivity to ara-C $(P=0.50)$ from a large group of AML samples that we have previously characterised for in vitro drug sensitivity (Hubeek et al, submitted; Zwaan et al, 2000) and was therefore considered to be representative.

mRNA expression levels of enzymes involved in the metabolism of deoxynucleoside analogues in AML and FAB-type subgroups

Using quantitative real-time PCR the mRNA expression levels of $h E N T 1, d C K, P N-I, C D A, d C M P d, R R 1, R R 2$ and CTPs were determined. Measurable amounts of all eight genes were found in

Table 2 Patient characteristics

\begin{tabular}{lc}
\hline Patient characteristics & $\mathbf{n}$ \\
\hline Sex (male: female) & $31: 19$ \\
Age, years (median, range) & $10.7(0.1-16.8)$ \\
WBC (median, range) & \\
FAB-type & \\
M0 & 2 \\
MI & 6 \\
M2 & 6 \\
M3 & 8 \\
M4 & 4 \\
M5 & 18 \\
Unknown & 9 \\
\hline
\end{tabular}

$\mathrm{WBC}=$ white blood cell count. all samples. Sample source (bone marrow $(n=37)$ or peripheral blood $(n=13)$ ) and the time interval between tissue acquisition and processing/storage of the cells (within 24 or $48 \mathrm{~h}$ ) did not influence mRNA expression of the enzymes and all samples were therefore evaluated together in the following analyses. Genes were expressed with considerable variability between various patients (Figure 2). We investigated the association between all eight genes and several diagnostic features. There was no difference in mRNA expression levels of target genes between boys and girls, nor was there a relation between the expression level of these genes and initial white blood cell (WBC) count.

For the analysis with $\mathrm{FAB}$-type, patients were divided into three subgroups: FAB M1/M2, FAB M4 and FAB M5. FAB M1/M2 were taken together because they did not differ in age, sex, WBC, drug resistance or mRNA expression levels (data not shown). FAB M0 and $\mathrm{FAB}$ M3 were excluded because of the limited number of samples. FAB M5 expressed 1.8-fold $(P=0.007)$ lower levels of $P N-I$ compared to FAB M1/M2. We did not observe any other significant differences (Table 3 ).

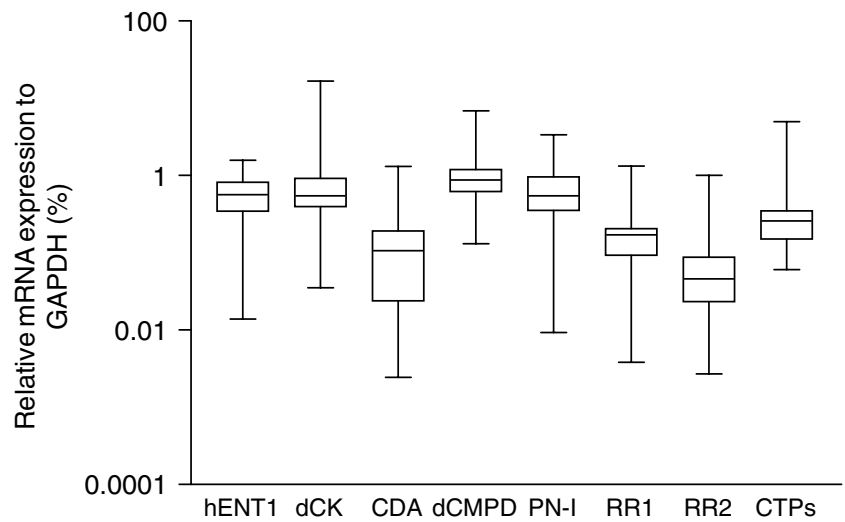

Figure 2 Expression levels of potential resistance factors to ara-C, determined by Taqman PCR. mRNA expression (relative to glyceraldehyde-3-phosphate dehydrogenase $(G A P D H)$ ) of the human equilibrative nucleoside transporter I (hENTI), deoxycytidine kinase (dCK), pyrimidine nucleotidase I $(P N-I)$, cytidine deaminase $(C D A)$, ribonucleotide reductase subunit I and 2 (RRI \& RR2) and CTP synthetase (CTPs) were determined by Taqman PCR in 50 paediatric AML samples, obtained at diagnosis. Measurable amounts of all genes were found in all patients. Targets were expressed with great variability; group medians, 25th/75th percentiles and the ranges are given.

Table 3 mRNA expression (relative to GAPDH (\%)) of hENTI and enzymes involved in ara- $C$ cytotoxicity in $A M L F A B$ type subgroups

\begin{tabular}{lccc}
\hline & $\begin{array}{c}\text { FAB MI/2 } \\
(\mathbf{n}=\mathbf{I 4 )}\end{array}$ & $\begin{array}{c}\text { FAB M4 } \\
(\mathbf{n}=\mathbf{I 8})\end{array}$ & $\begin{array}{c}\text { FAB M5 } \\
(\mathbf{n}=\mathbf{9})\end{array}$ \\
\hline hENTI & $0.68(0.30-0.76)$ & $0.51(0.33-0.75)$ & $0.57(0.48-0.95)$ \\
DCK & $0.61(0.45-1.34)$ & $0.52(0.42-0.89)$ & $0.55(0.17-0.85)$ \\
CDA & $0.069(0.009-0.24)$ & $0.14(0.06-0.20)$ & $0.16(0.08-0.21)$ \\
DCMPd & $1.09(0.72-1.56)$ & $0.89(0.70-1.19)$ & $0.60(0.52-1.09)$ \\
PN-I & $0.79(0.51-1.37)$ & $0.60(0.39-0.85)$ & $0.43(0.16-0.50) *$ \\
RRI & $0.18(0.11-0.29)$ & $0.15(0.06-0.22)$ & $0.15(0.08-0.22)$ \\
RR2 & $0.05(0.02-0.09)$ & $0.04(0.01-0.08)$ & $0.05(0.02-0.17)$ \\
CTPS & $0.28(0.20-0.32)$ & $0.20(0.14-0.33)$ & $0.34(0.17-0.47)$ \\
\hline
\end{tabular}

Values are the group median (25th-75th percentile). $* P<0.01$ compared to $F A B$ $\mathrm{MI} / 2$ 
Table 4 Correlation between mRNA level of potential resistance factors and in vitro sensitivity to deoxynucleoside analogues (expressed as $L_{50}$ values) in 50 paediatric AML samples obtained at initial diagnosis

\begin{tabular}{|c|c|c|c|c|c|c|}
\hline & & Ara-C & 2-CdA & DAC & F-ara-A & dFdC \\
\hline hENTI & $\stackrel{r}{P}_{P \text {-value }}$ & $\begin{array}{c}-0.46 * * \\
0.001\end{array}$ & $\begin{array}{c}-0.30 * \\
0.04\end{array}$ & $\begin{array}{c}-0.29 * \\
0.04\end{array}$ & $\begin{array}{r}-0.24 \\
0.09\end{array}$ & $\begin{array}{c}-0.38 * \\
0.02\end{array}$ \\
\hline$d C K$ & $\begin{array}{l}r_{\mathrm{P}} \\
P \text {-value }\end{array}$ & $\begin{array}{r}-0.11 \\
0.43\end{array}$ & $\begin{array}{r}-0.09 \\
0.55\end{array}$ & $\begin{array}{r}-0.04 \\
0.79\end{array}$ & $\begin{array}{l}0.004 \\
0.98\end{array}$ & $\begin{array}{c}-0.31 * \\
0.03\end{array}$ \\
\hline$C D A$ & $\begin{array}{l}r_{\mathrm{P}} \\
P \text {-value }\end{array}$ & $\begin{array}{l}0.13 \\
0.38\end{array}$ & $\begin{array}{r}-0.09 \\
0.57\end{array}$ & $\begin{array}{l}0.33 * \\
0.02\end{array}$ & $\begin{array}{l}0.06 \\
0.69\end{array}$ & $\begin{array}{l}0.001 \\
0.99\end{array}$ \\
\hline$d C K / P N-I$ & $\begin{array}{l}r_{p} \\
P \text {-value }\end{array}$ & $\begin{array}{r}-0.27 \\
0.06\end{array}$ & $\begin{array}{r}-0.09 \\
0.55\end{array}$ & $\begin{array}{r}-0.16 \\
0.29\end{array}$ & $\begin{array}{r}-0.26 \\
0.08\end{array}$ & $\begin{array}{c}-0.45 * * \\
0.001\end{array}$ \\
\hline$d C K / C D A$ & $\begin{array}{l}r_{\mathrm{p}} \\
P \text {-value }\end{array}$ & $\begin{array}{r}-0.17 \\
0.24\end{array}$ & $\begin{array}{l}0.02 \\
0.87\end{array}$ & $\begin{array}{l}0.29 * \\
0.04\end{array}$ & $\begin{array}{r}-0.05 \\
0.75\end{array}$ & $\begin{array}{r}-0.18 \\
0.23\end{array}$ \\
\hline
\end{tabular}

***arson correlation $\left(r_{p}\right)$ significant at the 0.01 level (two-tailed). *Pearson correlation $\left(r_{\mathrm{p}}\right)$ significant at the 0.05 level (two-tailed). Correlations between mRNA expression of $\mathrm{dCMPD}, P N-1, R R I, R R 2$ and CTPS, and in vitro sensitivity to deoxynucleoside analogues were not significant.

\section{In vitro cytotoxicity assay}

Dose-response curves were obtained for all drugs and marked differences between individual patients were found. The median (25th-75th percentile) ara-C $\mathrm{LC}_{50}$ value was $1.70 \mu \mathrm{M}(0.59-$ $3.38 \mu \mathrm{M} ; n=50)$, which is in concordance with results published previously (Zwaan et al, 2000). For the purine analogues 2-CdA and $\mathrm{F}$-ara-A group median $\mathrm{LC}_{50}$ values were $0.073 \mu \mathrm{M}(0.051-$ $0.098 \mu \mathrm{M} ; n=46)$ and $1.19 \mu \mathrm{m}(0.66-2.27 \mu \mathrm{M} ; n=47)$, respectively. The group median for $\mathrm{dFdC}$ was $10.04 \mu \mathrm{m}(2.05-20.86 \mu \mathrm{M} ; n=48)$, while DAC was only active in very high concentrations (median $\mathrm{LC}_{50}$ value $\left.=3426 \mu \mathrm{m}(717-5700 \mu \mathrm{M} ; n=48)\right)$.

\section{Correlations between mRNA expression levels and in vitro sensitivity to deoxynucleoside analogues}

$h E N T 1$ mRNA expression inversely correlated with the $\mathrm{LC}_{50}$ values of ara-C $\left(r_{\mathrm{p}}=-0.46 ; P=0.001 ; n=50\right)$ and also seemed to correlate inversely with the $\mathrm{LC}_{50}$ values of 2 -CdA $\left(r_{\mathrm{p}}=-0.30\right.$; $P=0.04 ; n=46)$, DAC $\left(r_{\mathrm{p}}=-0.29 ; P=0.04 ; n=48\right)$ and $\mathrm{dFdC}$ $\left(r_{\mathrm{p}}=-0.33 ; P=0.02 ; n=48\right)$. In other words, increased sensitivity to deoxynucleoside analogues was directly related to increased mRNA expression of the hENT1 nucleoside transporter. Furthermore, decreased $d C K$ mRNA expression seemed to correlate with resistance to $\mathrm{dFdC}\left(r_{\mathrm{p}}=-0.31 ; P=0.03 ; n=48\right)$. Also, resistance to DAC seemed to correlate with increased CDA mRNA levels $\left(r_{\mathrm{p}}=0.33 ; P=0.03 ; n=48\right)$. The accumulation of ara-CTP could depend on the ratio of the activation enzyme $\mathrm{dCK}$ and the inactivation enzymes $P N-I$ and $C D A$. Therefore, we also studied the relation between the $d C K / P N-I$ and $d C K / C D A$ ratios and in vitro drug sensitivity. The $d C K / P N-I$ ratio correlated inversely with the $\mathrm{LC}_{50}$ values for $\mathrm{dFdC}\left(r_{\mathrm{p}}=-0.45 ; P=0.001 ; n=47\right)$ and the $d C K /$ $C D A$ ratio seemed to correlate with the $L_{50}$ values for $D A C$ $\left(r_{\mathrm{p}}=-0.29 ; 0.04 ; n=48\right)$. We did not observe correlations between these ratios and in vitro sensitivity to ara-C, $2-\mathrm{CdA}$ and $\mathrm{F}$-ara (Table 4).

mRNA expression levels of hENT1, dCK, PN-I, CDA, dCMPd, $R R 1 / 2$ and CTPs were entered into a stepwise multivariate regression model to identify the most important indicators with respect to in vitro sensitivity to deoxynucleoside analogues (dependent variables $\mathrm{LC}_{50}$ values ara-C, 2-CdA, DAC, F-ara-A or dFdC). In multivariate analysis, hENT1 mRNA expression predicted in vitro sensitivity to ara-C $(P=0.002)$. Furthermore, $C D A$ mRNA expression levels seemed to predict in vitro sensitivity to DAC $(P=0.02)$, while other factors did not reach significance. Also, when we divided the AML samples in three subgroups based

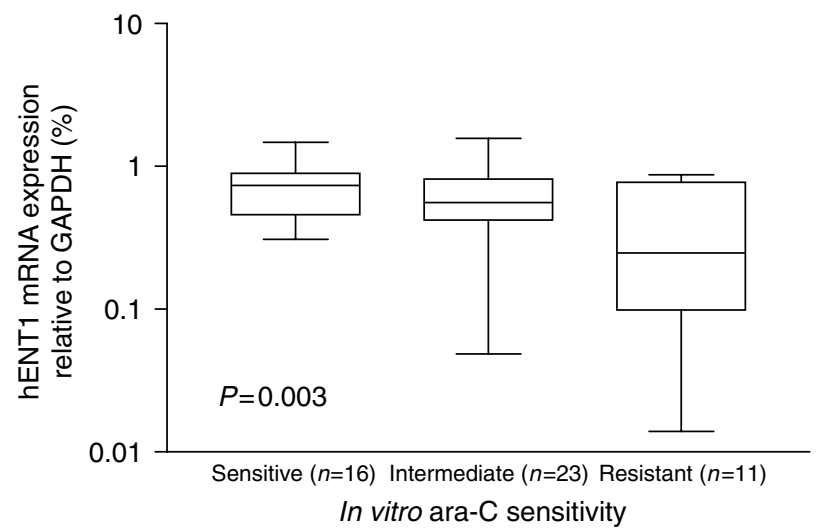

Figure 3 hENTI mRNA expression in relation to in vitro ara-C sensitivity. $\mathrm{AML}$ patient samples were divided into three groups based on in vitro ara- $C$ sensitivity (sensitive $=L C_{50}<0.98 \mu \mathrm{M}$ ), intermediate $=0.98<L_{50}$ $<5.18 \mu \mathrm{M}$ ) and resistant $=\mathrm{LC}_{50}>5.18 \mu \mathrm{M}$ ) (Zwaan et al, 2000). Patient resistant to ara- $C$ in vitro expressed 3.0 -fold lower hENTI mRNA levels compared to sensitive patients. The lines indicate the median value. $P$-value determined by one-way ANOVA.

on their in vitro ara-C sensitivity, resistant patients expressed three-fold lower hENT1 mRNA levels compared to sensitive patients $(P=0.003$; Figure 3$)$

\section{DISCUSSSION}

For AML, ara-C is the essential drug during induction and consolidation therapy and is given both at intermediate and highdose schedules (Bloomfield et al, 1998; Galmarini et al, 2002a). In the present study we analysed possible resistance factors to ara-C, and other clinically important deoxynucleoside analogues, in AML by measuring the gene expression of the major players in transport and metabolism of ara-C. Quantitative real-time PCR revealed that AML FAB-M5 expressed lower levels of the ara-C degrading enzyme $P N-I$ compared to FAB-M1/2. Although the analysis included only a limited number of samples, this finding may provide an explanation for the relative sensitivity to ara-C of AML FAB-M5 that we reported previously (Zwaan et al, 2000).

We studied the relation between the mRNA expression level of potential ara-C resistance factors and in vitro sensitivity to deoxynucleoside analogues. Although in vitro drug resistance testing differs considerably from the in vivo situation, it does provide valuable indications as to which factors might be important in drug sensitivity in vivo (Kaspers et al, 1999). hENT1 mRNA expression correlated with sensitivity to ara-C and also seemed to correlate with sensitivity to 2-CdA, DAC and dFdC, indicating that transport across the cell membrane is an important step for deoxynucleoside analogue induced cytotoxicity. In multivariate analysis, $h E N T 1$ mRNA expression was the most important factor determining sensitivity to ara-C. This might be explained by the fact that entry of ara-C into the cell is mainly dependent on hENT1-mediated transport (Wiley et al, 1982; Pastor-Anglada et al, 1998; Sundaram et al, 2001; Clarke et al, 2002). In contrast, 2-CdA, DAC and dFdC differ from ara-C with respect to their preferential nucleoside transporters and can be transported across the cell membrane by other members of the nucleoside transporter family as well (Damaraju et al, 2003). 2-CdA can enter cells via hENT1, hENT2 and the human concentrative nucleoside transporter (hCNT) 3 (Ritzel et al, 2001; Damaraju et al, 2003), while hENT1, hENT2, hCNT1 and hCNT3 are able to mediate uptake of dFdC into cells (Damaraju et al, 2003). hENT1 mediated influx however seems to be a pivotal factor in ara-C cytotoxicity. Patients 
resistant to ara-C in vitro expressed three-fold lower $h E N T 1$ mRNA levels. Our results are supported by the fact that hENT1 has been implicated as a crucial factor in ara-C sensitivity in previous studies (Galmarini et al, 2002b,c). Galmarini et al measured $h E N T 1$ mRNA expression in adult AML samples and demonstrated that $h E N T 1$ deficiency was related to a shorter disease-free survival (Galmarini et al, 2002c). In addition, elevated hENT1 mRNA expression explained the remarkable ara-C sensitivity of infants with $M L L$ gene-rearranged ALL (Stam et al, 2003). hENT1 may therefore be a valuable predictor of ara-C sensitivity at diagnosis. Unfortunately, we were not able to asses the relation between hENT1 expression and in vivo response to treatment due to the heterogenity of the treatment and the limited follow-up time. Patients were treated according to different treatment protocols and several different dosing schedules. AML patients may however benefit from screening for $h E N T 1$ mRNA levels at diagnosis, because of its significance for ara-C dosing. At intermediate dose ara-C $\left(100-200 \mathrm{mg} \mathrm{m}^{-2}\right)$ plasma levels are in the $\mu \mathrm{m}$ range and transport across the cell membrane is solely dependent on nucleoside transporters (Peters et al, 1993). At high-dose ara-C $\left(1-3 \mathrm{~g} \mathrm{~m}^{-2}\right)$, however, hENT1 seems less crucial although plasma concentrations might not exceed the $\mathrm{Km}$ of the transporter mediated influx. Ara-C may also enter by passive diffusion at this concentration, while dCK will be saturated (Capizzi et al, 1985; Bolwell et al, 1988). Patients with a low hENT1 mRNA level could potentially benefit from up-front high dose ara-C treatment or an ara- $C$ analogue that is not dependent on transporter-mediated influx. A compound such as troxacitabine, which passively diffuses across the cell membrane due to its unusual L-configuration (Gourdeau et al, 2001; Giles, 2002), might be able to circumvent ara-C resistance caused by low $h E N T 1$ expression.

Most studies on ara-C resistance have focussed on the conversion of ara-C to ara-CTP and several studies have linked reduced $d C K$ mRNA expression or functional activity to ara-C resistance (Owens et al, 1992; Stegmann et al, 1993; Kawasaki et al, 1996; Dumontet et al, 1999). In acute leukaemia, relapsed ALL and AML patients have been shown to express decreased dCK mRNA levels (Kakihara et al, 1998). In contrast, dCK was not rate-limiting in the formation of ara-CTP in infants with $M L L$ gene-rearranged ALL (Stam et al, 2003). In this present study, we did not observe a correlation between $d C K$ mRNA expression and in vitro ara-C sensitivity in AML blasts. Although there was a considerable range in $d C K$ mRNA levels in AML blasts, the median expression was quite high, and it therefore seems unlikely that low dCK expression plays a role in ara-C resistance in childhood AML at diagnosis. We have previously reported on $d C K$ mRNA levels in childhood AML blasts and most AML samples expressed mRNA leves that were in the range of cell lines sensitive to ara-C (van der Wilt et al, 2003). Reduced $d C K$ mRNA expression may however be involved in resistance to gemcitabine. Both $d C K$ mRNA and protein levels have been shown to predict in vivo gemcitabine sensitivity (Kroep et al, 2002). Our present study also indicated that reduced $d C K$ mRNA expression may contribute to in vitro gemcitabine resistance in AML blasts. It should be mentioned, however, that the Pearson correlation coefficient was low and was not significant in multivariate analysis.

Finally, multivariate analysis showed that DAC resistance seemed to correlate with increased mRNA levels of the inactivating enzyme CDA. DAC was initially developed as a cytotoxic agent and has activity in several haematological malignancies. Low-dose DAC is currently enjoying a revival as a specific inhibitor of DNA hypermethylation in cancer (Lyons et al, 2003). DAC is an excellent substrate for CDA and elevated $C D A$ mRNA levels might contribute to resistance to DAC (Momparler, 1985).

In conclusion, our findings indicate that reduced drug influx into the cell caused by decreased $h E N T 1$ mRNA expression might be involved in resistance to ara-C, and other deoxynucleoside analogues, in childhood AML.

\section{ACKNOWLEDGEMENTS}

We thank all hospitals and clinicians participating in the MRC Childhood Leukaemia Working Party, AML-BFM Study Group and the DCOG who provided us with patient samples. This study was performed within the setting of the I-BFM-SG (AML committee; chairman, GJL Kaspers). We would also like to thank the technicians of the Laboratory of Pediatric Hematology/Oncology at the Vumc for performing the drug resistance testing.

\section{REFERENCES}

Amici A, Emanuelli M, Magni G, Raffaelli N, Ruggieri S (1997) Pyrimidine nucleotidases from human erythrocyte possess phosphotransferase activities specific for pyrimidine nucleotides. FEBS Lett 419: 263-267

Bennett JM, Catovsky D, Daniel MT, Flandrin G, Galton DA, Gralnick HR, Sultan C (1985) Proposed revised criteria for the classification of acute myeloid leukemia. A report of the French-American-British Cooperative Group. Ann Intern Med 103: 620-625

Bloomfield CD, Lawrence D, Byrd JC, Carroll A, Pettenati MJ, Tantravahi R, Patil SR, Davey FR, Berg DT, Schiffer CA, Arthur DC, Mayer RJ (1998) Frequency of prolonged remission duration after high-dose cytarabine intensification in acute myeloid leukemia varies by cytogenetic subtype. Cancer Res 58: 4173-4179

Bolwell BJ, Cassileth PA, Gale RP (1988) High dose cytarabine: a review. Leukemia 2: 253-260

Capizzi RL, Yang JL, Rathmell JP, White JC, Cheng E, Cheng YC, Kute T (1985) Dose-related pharmacologic effects of high-dose ara-C and its self-potentiation. Semin Oncol 12: 65-74

Cass CE, Young JD, Baldwin SA (1998) Recent advances in the molecular biology of nucleoside transporters of mammalian cells. Biochem Cell Biol 76: $761-770$

Clarke ML, Mackey JR, Baldwin SA, Young JD, Cass CE (2002) The role of membrane transporters in cellular resistance to anticancer nucleoside drugs. Cancer Treat Res 112: 27-47

Creutzig U, Harbott J, Sperling C, Ritter J, Zimmermann M, Loffler H, Riehm H, Schellong G, Ludwig WD (1995) Clinical significance of surface antigen expression in children with acute myeloid leukemia: results of study AML-BFM-87. Blood 86: $3097-3108$

Creutzig U, Zimmermann M, Ritter J, Henze G, Graf N, Loffler H, Schellong G (1999) Definition of a standard-risk group in children with AML. $B r J$ Haematol 104: 630-639

Damaraju VL, Damaraju S, Young JD, Baldwin SA, MacKey J, Sawyer MB, Cass CE (2003) Nucleoside anticancer drugs: the role of nucleoside transporters in resistance to cancer chemotherapy. Oncogene 22: $7524-7536$

Dumontet C, Fabianowska-Majewska K, Mantincic D, Callet BE, Tigaud I, Gandhi V, Lepoivre M, Peters GJ, Rolland MO, Wyczechowska D, Fang X, Gazzo S, Voorn DA, Vanier-Viornery A, MacKey J (1999) Common resistance mechanisms to deoxynucleoside analogues in variants of the human erythroleukaemic line K562. Br J Haematol 106: 78-85

Frewin RJ, Johnson SA (2001) The role of purine analogue combinations in the management of acute leukemias. Hematol Oncol 19: 151-157

Galmarini CM, Mackey JR, Dumontet C (2002a) Nucleoside analogues and nucleobases in cancer treatment. Lancet Oncol 3: 415-424

Galmarini CM, Thomas X, Calvo F, Rousselot P, Jafaari AE, Cros E, Dumontet C (2002b) Potential mechanisms of resistance to cytarabine in AML patients. Leuk Res 26: 621-629

Galmarini CM, Thomas X, Calvo F, Rousselot P, Rabilloud M, El Jaffari A, Cros E, Dumontet C (2002c) In vivo mechanisms of resistance to cytarabine in acute myeloid leukaemia. Br J Haematol 117: $860-868$ 
Giles FJ (2002) Novel agents for the therapy of acute leukemia. Curr Opin Oncol 14: 3-9

Gourdeau H, Clarke ML, Ouellet F, Mowles D, Selner M, Richard A, Lee N, Mackey JR, Young JD, Jolivet J, Lafreniere RG, Cass CE (2001) Mechanisms of uptake and resistance to troxacitabine, a novel deoxycytidine nucleoside analogue, in human leukemic and solid tumor cell lines. Cancer Res 61: 7217-7224

Grant S (1998) Ara-C: cellular and molecular pharmacology. Adv Cancer Res 72: $197-233$

Hande KR, Chabner BA (1978) Pyrimidine nucleoside monophosphate kinase from human leukemic blast cells. Cancer Res 38: 579-585

Hann IM, Webb DK, Gibson BE, Harrison CJ (2004) MRC trials in childhood acute myeloid leukaemia. Ann Hematol 83(Suppl 1): S108-S112

Kakihara T, Fukuda T, Tanaka A, Emura I, Kishi K, Asami K, Uchiyama M (1998) Expression of deoxycytidine kinase (dCK) gene in leukemic cells in childhood: decreased expression of dCK gene in relapsed leukemia. Leuk Lymphoma 31: 405-409

Kaspers GJ, Kardos G, Pieters R, van Zantwijk CH, Klumper E, Hahlen K, de Waal FC, Van Wering ER, Veerman AJ (1994a) Different cellular drug resistance profiles in childhood lymphoblastic and non-lymphoblastic leukemia: a preliminary report. Leukemia 8: 1224-1229

Kaspers GJ, Pieters R, van Zantwijk CH, De Laat PA, de Waal FC, Van Wering ER, Veerman AJ (1991) In vitro drug sensitivity of normal peripheral blood lymphocytes and childhood leukaemic cells from bone marrow and peripheral blood. Br J Cancer 64: 469-474

Kaspers GJ, Veerman AJ, Pieters R, Broekema GJ, Huismans DR, Kazemier KM, Loonen AH, Rottier MA, van Zantwijk CH, Hahlen K (1994b) Mononuclear cells contaminating acute lymphoblastic leukaemic samples tested for cellular drug resistance using the methyl-thiazoltetrazolium assay. $\mathrm{Br}$ J Cancer 70: $1047-1052$

Kaspers GJ, Zwaan CM, Veerman AJ, Rots MG, Pieters R, Bucsky P, Domula M, Gobel U, Graf N, Havers W, Jorch N, Kabisch K, Spaar HJ, Ritter J, Creutzig U (1999) Cellular drug resistance in acute myeloid leukemia: literature review and preliminary analysis of an ongoing collaborative study. Klin Padiatr 211: 239-244

Kawasaki H, Shindou K, Higashigawa M, Cao DC, Hori H, Ido M, Sakurai M (1996) Deoxycytidine kinase mRNA levels in leukemia cells with competitive polymerase chain reaction assay. Leuk Res 20: 677-682

Klumper E, Pieters R, Kaspers GJ, Huismans DR, Loonen AH, Rottier MM, Van Wering ER, Van der Does-Van den Berg A, Hahlen K, Creutzig U (1995) In vitro chemosensitivity assessed with the MTT assay in childhood acute non-lymphoblastic leukemia. Leukemia 9: 1864-1869

Kroep JR, Loves WJ, van der Wilt CL, Alvarez E, Talianidis L, Boven E, Braakhuis BJ, Van Groeningen CJ, Pinedo HM, Peters GJ (2002) Pretreatment deoxycytidine kinase levels predict in vivo gemcitabine sensitivity. Mol Cancer Ther 1: 371-376

Laliberte J, Momparler RL (1994) Human cytidine deaminase: purification of enzyme, cloning, and expression of its complementary DNA. Cancer Res 54: $5401-5407$

Liliemark JO, Plunkett W (1986) Regulation of 1-beta-D-arabinofuranosylcytosine $5^{\prime}$-triphosphate accumulation in human leukemia cells by deoxycytidine 5'-triphosphate. Cancer Res 46: 1079-1083

Liliemark JO, Plunkett W, Dixon DO (1985) Relationship of 1-beta-Darabinofuranosylcytosine in plasma to 1-beta-D-arabinofuranosylcytosine 5 -triphosphate levels in leukemic cells during treatment with high-dose 1-beta-D-arabinofuranosylcytosine. Cancer Res 45: 5952 - 5957

Lyons J, Bayar E, Fine G, McCullar M, Rolens R, Rubinfeld J, Rosenfeld C (2003) Decitabine: development of a DNA methyltransferase inhibitor for hematological malignancies. Curr Opin Invest Drugs 4: $1442-1450$

Mancini WR, Cheng YC (1983) Human deoxycytidylate deaminase. Substrate and regulator specificities and their chemotherapeutic implications. Mol Pharmacol 23: $159-164$

Meijerink J, Mandigers C, van de LL, Tonnissen E, Goodsaid F, Raemaekers J (2001) A novel method to compensate for different amplification efficiencies between patient DNA samples in quantitative real-time PCR. J Mol Diagn 3: 55-61

Momparler RL (1985) Molecular, cellular and animal pharmacology of 5-aza-2'-deoxycytidine. Pharmacol Ther 30: 287-299
Owens JK, Shewach DS, Ullman B, Mitchell BS (1992) Resistance to 1-betaD-arabinofuranosylcytosine in human T-lymphoblasts mediated by mutations within the deoxycytidine kinase gene. Cancer Res 52: $2389-2393$

Pastor-Anglada M, Felipe A, Casado FJ (1998) Transport and mode of action of nucleoside derivatives used in chemical and antiviral therapies. Trends Pharmacol Sci 19: 424-430

Peters GJ, Schornagel JH, Milano GA (1993) Clinical pharmacokinetics of anti-metabolites. Cancer Surv 17: 123-156

Pieters R, Loonen AH, Huismans DR, Broekema GJ, Dirven MW, Heyenbrok MW, Hahlen K, Veerman AJ (1990) In vitro drug sensitivity of cells from children with leukemia using the MTT assay with improved culture conditions. Blood 76: $2327-2336$

Plunkett W, Liliemark JO, Estey E, Keating MJ (1987) Saturation of ara-CTP accumulation during high-dose ara-C therapy: pharmacologic rationale for intermediate-dose ara-C. Semin Oncol 14: 159-166

Reichard P, Ehrenberg A (1983) Ribonucleotide reductase - a radical enzyme. Science 221: 514-519

Ritzel MW, Ng AM, Yao SY, Graham K, Loewen SK, Smith KM, Ritzel RG Mowles DA, Carpenter P, Chen XZ, Karpinski E, Hyde RJ, Baldwin SA, Cass CE, Young JD (2001) Molecular identification and characterization of novel human and mouse concentrative $\mathrm{Na}+$-nucleoside cotransporter proteins (hCNT3 and mCNT3) broadly selective for purine and pyrimidine nucleosides (system cib). J Biol Chem 276: 2914-2927

Slats AM, Egeler RM, Van der Does-Van den Berg A, Korbijn C, Hahlen K, Kamps WA, Veerman AJ, Zwaan CM (2005) Causes of death - other than progressive leukemia - in childhood acute lymphoblastic (ALL) and myeloid leukemia (AML): the Dutch Childhood Oncology Group experience. Leukemia 19: 537-544

Smith BD, Karp JE (2003) Ribonucleotide reductase: an old target with new potential. Leuk Res 27: $1075-1076$

Stam RW, Den Boer ML, Meijerink JP, Ebus ME, Peters GJ, Noordhuis P, Janka-Schaub GE, Armstrong SA, Korsmeyer SJ, Pieters R (2003) Differential mRNA expression of Ara-C-metabolizing enzymes explains Ara-C sensitivity in MLL gene-rearranged infant acute lymphoblastic leukemia. Blood 101: 1270-1276

Stegmann AP, Honders MW, Kester MG, Landegent JE, Willemze R (1993) Role of deoxycytidine kinase in an in vitro model for AraC- and DACresistance: substrate-enzyme interactions with deoxycytidine, 1-beta-Darabinofuranosylcytosine and 5-aza-2'-deoxycytidine. Leukemia 7: $1005-1011$

Sundaram M, Yao SY, Ingram JC, Berry ZA, Abidi F, Cass CE, Baldwin SA, Young JD (2001) Topology of a human equilibrative, nitrobenzylthioinosine (NBMPR)-sensitive nucleoside transporter (hENT1) implicated in the cellular uptake of adenosine and anti-cancer drugs. J Biol Chem 276: $45270-45275$

van der Wilt CL, Kroep JR, Loves WJ, Rots MG, Van Groeningen CJ, Kaspers GJ, Peters GJ (2003) Expression of deoxycytidine kinase in leukaemic cells compared with solid tumour cell lines, liver metastases and normal liver. Eur J Cancer 39: 691-697

Van Moorsel CJ, Peters GJ, Pinedo HM (1997) Gemcitabine: future prospects of single-agent and combination studies. Oncologist 2: $127-134$

Verschuur AC, Van Gennip AH, Muller EJ, Voute PA, Van Kuilenburg AB (1998) Increased activity of cytidine triphosphate synthetase in pediatric acute lymphoblastic leukemia. Adv Exp Med Biol 431: 667-671

White JC, Capizzi RL (1991) A critical role for uridine nucleotides in the regulation of deoxycytidine kinase and the concentration dependence of 1-beta-D-arabinofuranosylcytosine phosphorylation in human leukemia cells. Cancer Res 51: $2559-2565$

Wiley JS, Jones SP, Sawyer WH, Paterson AR (1982) Cytosine arabinoside influx and nucleoside transport sites in acute leukemia. J Clin Invest 69: $479-489$

Zwaan CM, Kaspers GJ, Pieters R, Ramakers-Van Woerden NL, Den Boer ML, Wunsche R, Rottier MM, Hahlen K, Van Wering ER, Janka-Schaub GE, Creutzig U, Veerman AJ (2000) Cellular drug resistance profiles in childhood acute myeloid leukemia: differences between FAB types and comparison with acute lymphoblastic leukemia. Blood 96: 2879-2886 